\title{
Tradisi Pemindahan Perempuan dalam Perkawinan Adat Masyarakat Nyura Lele Suku Wee Leo Kabupaten Sumba Barat Daya
}

\author{
Zedi Muttaqin', Hafsah² Yuan Aristo Malo3
}

\footnotetext{
${ }^{1}$ Pendidikan Pancasila dan Kewarganegaraan, Universitas Muhammadiyah Mataram, Email: zedi.muttaqin@gmail.com

${ }^{2}$ Pendidikan Pancasila dan Kewarganegaraan, Universitas Muhammadiyah Mataram, Email: dansa machi@yahoo.co.id

${ }^{3}$ Pendidikan Pancasila dan Kewarganegaraan, Universitas Muhammadiyah Mataram, Email: yuan.aristomalo13@gmail.com
}

\section{INFO ARTIKEL \\ Riwayat Artikel: \\ Diterima: 18-Maret-2020 \\ Disetujui: 28-Maret-2020}

\section{Kata Kunci: \\ Tradisi \\ Pemindahan \\ Perempuan \\ Perkawinan \\ Adat}

\begin{abstract}
ABSTRAK
Abstrak: Perkawinan adat Sumba, suatu hal yang masih melekat hingga saat ini yaitu tradisi pemindahan perempuan sebagai salah satu tahapan yang harus di lalui agar perkawinan dikatakan sah dan dapat dijemput oleh keluarga laki-laki. Perkembangan zaman dan peradaban yang semakin maju, akhirnya tradisi ini tidak berjalan sesuai dengan kebiasaan yang telah disepakati. Metode yang digunakan dalam penelitian ini yaitu metode kualitatif dengan pendekatan fenomologi. Dalam penelitian ini peneliti menggunakan sumber data primer di peroleh melalui hasil wawancara sedangkan data sekunder diperoleh melalui dokumen-dokumen dan informasi lain yang terkait dengan penelitian. Teknik pengumpulan data yang digunakan adalah observasi, wawancara dan dokumentasi. Hasil penelitian menunjukkan proses Tradisi pemindahan perempuan (Padikina Minne Pala Koro Burru Nauta) pada perkawinan adat masyarakat desa Nyura Lele suku Wee Leo kabupaten Sumba Barat Daya meliputi tahapan perkenalan, tahapan perkenalan adat, tahapan ikat adat dan tahapan pindah dinding turun tangga/ikat pindah. Dalam proses pelaksanan tradisi pemindahan perempuan dalam istilah masyarakat Sumba disebut padikkina mine pala koro burru nauta (pemindahan perempuan/ mempelai wanita pindah dinding turun tangga) meliputi yaitu membuka/memulai pembicaraan, pemberian Tagu Loka (bagian om/paman), pemberian Tagu Umma Kalada (Belis untuk rumah besar), pemberian Imbalan Air Susu Ibu (Itta Kere Puaro Mata), dan urusan Belis.
\end{abstract}

\begin{abstract}
The traditional wedding of Sumba, a thing that is still inherent to the present is the tradition of Padikkina Minne mone nutmeg Velvet (the transfer of women/brides moved the wall down the stairs) as one of the stages that must be passed so that the marriage is said to be valid and can be picked up by the male family. The development of the time and civilization is progressing, eventually this tradition does not go according to the agreed habit. The method used in this research is a qualitative method with a phenyomological approach. In this research researchers use primary data sources in obtaining through the results of interviews while secondary data is obtained through documents and other information related to the study. The data collection techniques used are observations, interviews and documentation. The results of the study showed the process of women's removal tradition (Padikina Minne Pala Koro Burru Nauta) on the indigenous marriage of the villagers Nyura Lele tribe Wee the West Sumba Regency Power includes the introductory stage, the stage of customary introduction, the stage of customary ikat and the stage of moving the wall down stairs In the process of the tradition of the removal of women in the community term Sumba called Padikkina mine pala Koro burru Nauta (Transfer of women/bride moving Wall down stairs) covering the opening/starting talks, giving Tagu Loka (part om/uncle), giving Tagu Umma Kalada (Belis for Big House), giving breast milk (Itta Kere Puaro Mata), and Belis affairs.
\end{abstract}

\section{A. LATAR BELAKANG}

Adat merupakan pencerminan dari pada kepribadian suatu bangsa, merupakan salah satu penjelmaan daripada jiwa bangsa yang bersangkutan dari abad ke abad. Maka dari itu, tiap-tiap bangsa di dunia ini memiliki adat kebiasaan/ tradisi sendiri- sendiri yang berbeda antara satu dengan yang lainnya. Oleh karena perbedaan itulah maka dapat merupakan unsur terpenting yang memberikan identitas kepada bangsa yang bersangkutan. Adat merupakan tata kelakuan yang mengatur, mengendali dan memberi arah kepada kelakuan dan perbuatan manusia dalam masyarakat. Para warga masyarakat dalam kebersamaan 
hidupnya sehari-hari melaksanakan aturan-aturan yang terdapat dalam adat tersebut, dengan demikian maka adat adalah aturan tingkah laku dalam suatu masyarakat adat tertentu [1].

Kajian literature sebelumnya menemukan, pernikahan adat Sumba mewajibkan calon mempelai pria untuk memenuhi syarat-syarat pernikahan seperti membawa kuda, emas, dan sarung sumba. Jika tidak dipenuhi lamaran akan ditolak. Sementara hukum keluarga Islam peminangan tidak diwajibkan jadi dilakukan atau tidak, tidak ada masalah [2]. Perkawinan adat Sumba mensyaratkan peminangan (belis) sebagai kesungguhan seorang laki-laki meminang seorang calon istri yang akan dilamarnya. Adanya Belis bertujuan menciptakan keluarga yang kukuh hingga akhir hayat dalam ikatan keluarga yang kuat [3]. Lainnya menemukan bahwa pernkahan adat Sumba pengaruh Belis berupa harta kawin yang dibawa pada saat proses peminangan oleh laki-laki kepada calon mempelai perempuan sangat dominan, dalam prosesnya semuanya harus seimbang [4]. Literature sebelumnya tersebut telah melakukan penelitian kajian hukum islam dan hukum adat masyarakat Sumba dalan perkawinan adat, kajian belis dalam pernikahan adat, pengaruh Belis dalam pernikahan adat masyarakat Sumba. Sementara paper ini memposisikan kajian yakni tradisi pemindahan perempuan/mempelai wanita pindah dinding turun tangga pada perkawinan adat masyarakat Desa Nyuralele Kabupaten Sumba Barat Daya.

Tradisi pemindahan perempuan Sumba cukup berbeda dengan daerah lain, tradisi pemindahan perempuan merupakan proses yang harus dilaksanakan mulai perkenalan/pendekatan dari pihak keluarga lakilaki untuk menyatakan keinginannya, penetapan waktu untuk pertemuan keluarga kedua belah pihak, penetapan mas kawin (belis atau mahar) bagi wanita yang dipinang. Hal yang akan dilakukan dalam paper ini mengidentifikasi dan menjelaskan mengapa perlu ada pemindahan perempuan secara adat dalam perkawinan adat desa Nyuralele Kabupaten Sumba Barat Daya, menjelaskan proses pemindahan perempuan secara pernikahan adat Sumba. Kondisi hingga kini adat kebiasaan/tradisi yang dianut masyarakat Sumba masih sangat kuat, salah satunya adat perkawinan. Perkawinan adat tersebut harus melalui tata aturan adat yang sudah menjadi tradisi dan turun-temurun dari satu generasi kegenerasi berikutnya.

Perkawinan merupakan prosesi sakral dalam kehidupan manusia. Undang-Undang Nomor 1 Tahun 1974 Pasal 1 menyatakan bahwa "perkawinan adalah ikatan lahir batin antara seorang pria dan seorang wanita sebagai suami istri dengan tujuan membentuk keluarga atau rumah tangga yang bahagia dan kekal berdasarkan Ketuhanan Yang Maha Esa”. Pada Pasal 2 menyatakan bahwa "perkawinan dinyatakan sah apabila dilakukan menurut hukum masing-masing agama dan kepercayaannya, serta tiap-tiap pernikahan dicatat menurut peraturan berlaku"[5].

perundang-undangan

yang

Dalam perkawinan adat Sumba, suatu hal yang masih melekat hingga saat ini yaitu tradisi padikkina minne pala koro burru nauta (pemindahan perempuan/ mempelai wanita pindah dinding turun tangga) pada masyarakat Desa Nyurulele Suku Wee Leo Kabupaten Sumba Barat Daya, dimana setiap orang yang akan melangsungkan perkawinan harus melalui proses yang cukup panjang dimulai dari perkenalan/pendekatan dari pihak keluarga laki-laki untuk menyatakan keinginannya, penetapan waktu untuk pertemuan keluarga kedua belah pihak, penetapan mas kawin (belis atau mahar) bagi wanita yang dipinang, aturan palaksanaan pembayaran mas kawin hingga acara pernikahannya tergangtung kesepakatan keluarga mempelai laki-laki maupun mempelai perempuan.

Perkembangan jaman dan peradaban yang semakin maju serta meningkatnya ilmu pengetahuan dan teknologi, tradisi padikkina minne pala koro burru nauta (pemindahan perempuan/mempelai wanita pindah dinding turun tangga) pada pada perkawinan adat masyarakat Desa Nyuralele Kabupaten Sumba Barat Daya sudah tidak lagi dilaksanakan sebagaimana mestinya. Misalnya proses yang harus dilaksanakan tahap demi mulai perkenalan/pendekatan dari pihak keluarga laki-laki untuk menyatakan keinginannya, penetapan waktu untuk pertemuan keluarga kedua belah pihak, penetapan mas kawin (belis atau mahar) bagi wanita yang dipinang, aturan pelaksanaan pembayaran mas kawin hingga acara pernikahannya sudah tidak lagi dilaksanakan sesuai dengan tahapan yang telah disepakati dengan alasan efesiensi waktu dan biaya, minimnya pengetahuan serta kurangnya pendampingan dari tokoh masyarakat adat yang mempunyai keahlihan dan pengalaman di bidang ini. Selain itu juga bahwa penelitian terdahulu belum membahas secara menyeluruh dan konprehensif mengenai tradisi padikkina minne pala koro burru nauta (pemindahan perempuan/mempelai wanita pindah dinding turun tangga). Sehingga tradisi ini mulai memudar dalam kehidupan masyarakat Desa Nyurulele dan akan berdampak pada kelestarian budaya serta kepada generasi penerusnya.

Tradisi ini meliputi tahapa-tahapan yang panjang dan kompleks. Tahap-tahap tersebut harus dilewati satu demi satu dengan jangka waktu yang telah disepakati bersama oleh keluarga kedua mempelai baik wanita maupun laki-laki dan setiap tahap tersebut mempunyai aturan pelaksanaan sendiri-sendiri serta mengandung nilai-nilai budaya yang harus tetap dijaga keluhurannya, yang bilamana aturan-aturan atau kaidah-kaidah yang telah ditetapkan itu tidak dipenuhi atau dilanggar akan memiliki sanksi sesuai yang ditetapkan oleh adat daerah tersebut. Penetapan-penetapan tersebut mempunyai kekuatan yang mengikat, yang harus dijadikan pedoman dalam suatu adat perkawinan. Apabila terdapat 
penyimpangan atau pelanggaran atas apa yang telah ditetapkan maka yang melanggar akan diadili dan dikenai sanksi sesuai dengan aturan adat yang telah disepakati dan ditetapkan, sanksi atas adanya suatu pelanggaran terhadap adat perkawinan di daerah Sumba umumnya berat tidak saja berdampak pada keluarga kedua belah pihak, tetapi seluruh masyarakat penganut adat tersebut turut menilai dan menghukum dalam arti mencemooh.

Selain itu pula menurut kepercayaan masyarakat sumba, di kemudian hari nanti dalam menjalani kehidupan rumah tangganya akan ada yang mengalami sakit serta musibah- musibah lain sebagai pertanda bahwa kedua mempelai tersebut harus menyelesaikan urusan adat perkawinan mereka sesuai aturan adat atau tradisi yang telah ditetapkan. Oleh karena itu untuk melaksanakan suatu perkawinan, keluarga kedua mempelai baik laki-laki maupun perempuan harus penuh pertimbangan dan ketetapan. Karena suatu pernikahan yang telah terjadi akan sulit sekali untuk diputuskan, tetapi bersifat kekal.

Dalam aturan perkwinan menurut undang-undang No. 1 tahun 1974 tentang syarat sah perkawinan. Dilihat dari sudut pandang Hukum Perjanjian [6], perkawinan merupakan perjanjian di lapangan hukum keluarga dan sesuai dengan ketentuannya sifat perjanjiannya dikategorikan sebagai perjanjian formil, artinya perjanjian lahir dan mengikat secara sah apabila dipenuhinya syarat-syarat serta tatacara (formalitas) perkawinan menurut UU No. 1 Tahun 1974 jo. PP No. 9 Tahun 1975. Kemudian dilihat dari aspek mengikatnya, fungsi pencatatan perkawinan secara yuridis merupakan persyaratan supaya perkawinan tersebut mendapatkan pengakuan dan perlindungan hukum dari negara serta mengikat pihak ke tiga (orang lain). Dipandang dari aspek regulasi maka tatacara dan pencatatan perkawinan mencerminkan suatu kepastian hukum, dengan ditentukannya bahwa suatu peristiwa perkawinan terjadi dibuktikan dengan adanya akta perkawinan.

Tradisi tersebut cukup menarik untuk jelaskan secara mendalam, karena tradisi ini berbeda dengan daerah lain di pulau sumba bahkan di Indonesia. Berbagai permasalahan tersebut, maka tujuan dalam artikel ini untuk menjelaskan tradisi pemindahan perempuan dalam perkawinan adat masyarakat Nyura Lele Suku Wee Leo kabupaten Sumba Barat Daya.

\section{B. METODE PENELITIAN}

1. Metode dan Pendekatan Penelitian

Penelitian ini menggunakan metode kualitatif dengan pendekatan fenomologi yang bertujuan untuk mendapatkan data tentang tradisi padikkina minne pala koro burru nauta (pemindahan perempuan/mempelai wanita pindah dinding turun tanga) pada masyarakat Desa Nyurulele suku Wee Leo, yaitu berusaha menggambarkan fakta dan kenyataan sosial kemudian dianalisis dengan menggunakan pengetahuan, ide-ide, konsep yang ada dalam kebudayaan masyarakat Desa Nyurulele Kabupaten Sumba Barat Daya.

\section{Metode Penentuan Subjek}

Dalam penelitian ini, penentuan informan dilakukan dengan cara purposive sampling. Adapun yang menjadi informan kunci dalam penelitian ini adalah Penduduk asli masyarakat desa Nyurulele, Laki-laki berusia 40 tahun ke atas (tidak pikun), ketua adat suku Wee Leo, dan pemerhati budaya atau tokoh masyarakat yang juga mengetahui Tradisi Padikkina minne pala koro burru nauta (pemindahan perempuan/ mempelai wanita pindah dinding turun tangga) pada perkawinan adat masyarakat Desa Nyurulele Suku Wee Leo Kabupaten Sumba Barat Daya.

\section{Metode Pengumpulan Data}

Data dalam penelitian ini dikumpulkan dengan berbágai cara yang disesuaikan dengan informasi yang diinginkan, antara lain dilakukan dengan melakukan observasi, wawancara dan dokumentasi. Dalam kegiatan observasi yang diobservasikan oleh peneliti adalah kehidupan sosial budaya masyarakat, terutama yang berkaitan dengan Pola Pelaksanaan Tradisi padikkina mine pala koro burru nauta (pemindahan perempuan/mempelai wanita pindah dinding turun tangga) pada perkawinan adat masyarakat Desa Nyurulele Suku Wee Leo Kabupaten sumba Barat Daya. Wawancara yang digunakan berupa wawancara tidak berstruktur, agar setiap jawaban dari responden tersebut lebih terarah pada suatu tujuan. Dalam melakukan wawancara peneliti dapat menggunakan cara berputarputar baru menukik artinya pada awal wawancara yang dibicarakan adalah hal-hal yang tidak terkait dengan tujuan, dan bila sudah terbuka kesempatan untuk menanyakan sesuatu yang menjadi tujuan, maka segera ditanyakan. Dokumentasi digunakan untuk mendapatkan data berupa foto, catatan atau data-data seperti tulisan tentang tradisi perkawinan adat masyarakat Desa Nyurulele Suku Wee Leo Kabupaten Sumba Barat Daya.

\section{Analisis Data}

Analisis data menggunakan tiga tahapan yakni reduksi data, penyajian data, dan verifikasi serta penarikan kesimpulan berdasarkan data yang dikumpulkan. Secara teknik analisis data terbagi menjadi tiga bagian yang pertama, reduksi data yaitu untuk merangkum, memilih hal-hal yang pokok, memfokuskan pada hal-hal yang penting dan pencarian tema serta pola. Kedua, penyajian data digunakan untuk menarik kesimpulan dari beberapa data yang bersifat umum menjadi kesimpulan yang bersifat sementara untuk merencanakan kerja selanjutnya berdasarkan apa yang dipahami. Ketiga, ialah penarikan kesimpulan dan memverifikasi data yang telah diperoleh di lapangan dan kemudian menguji kebenarannya, kekokohannya, dan 
kesesuaiannya melalui bukti-bukti yang ditemukan selama penelitian berlangsung sehingga mendapatkan simpulan yang objektif.

\section{HASIL DAN PEMBAHASAN}

\section{Proses pelaksanaan perkawinan}

Adat perkawinan Sumba Barat Daya merupakan tradisi turun temurun yang dilakukan hingga sekarang, tradisi ini merupakan prosesi yang sangat sakral, Prosesi adat padikkina mine pala koro burru nauta (pemindahan perempuan/ mempelai wanita pindah dinding turun tangga) pada masyarakat Desa Nyura Lele merupakan salah satu tahap yang harus dilewati dalam upacara perkawinan adat dimana pada tahap ini, pihak Keluarga laki-laki menjemput mempelai perempuan. Karena pada hakikatnya, hukum perkawinan masyarakat Desa Nyura Lele bersifat Patriakal (Perempuan pindah ikut suami).

Dalam tradisi budaya masyarakat Desa Nyura Lele, Kecamatan Wewewa Timur Kabupaten Sumba Barat Daya, tata cara pelaksanaan upacara perkawinan adat padikkina mine pala koro burru nauta (pemindahan perempuan/ mempelai wanita pindah dinding turun tangga) dilaksanakan sebagai berikut;

a. Tahap perkenalan

Perkawinan yang dilakukan biasanya melibatkan suku (kabisu). Jika ada dua suku yang masih merupakan kabisu (suku) bersaudara karena berasal dari satu leluhur maka diantara kabisu (suku) itu tidak boleh terjadi kawin-mawin. Selain perkawinan antara anak om/paman dan anak tante yang sangat dianjurkan tak dapat dihindari juga perkawinan yang terjadi atas kemauan dan atas dasar cinta dari anak-anak sendiri. Sebelum memasuki tahapan-tahapan adat diperlukan proses perkenalan agar dari kedua pihak keluarga mengetahui dengan jelas identitas atau status dan keturunan dari bua wine (perempuan) maupun bua mane (laki-laki).

b. Tahap perkenalan adat (dengi winni pare, winni watara)

Pada tahap ini utusan pria berangkat dari keluarga pria, mereka bersiap dalam satu kesatuan keluarga yang disebut doma (keluarga mempelai laki-laki) atau biasa disebut klen penerima wanita. Setelah sampai di rumah wanita, pembicaraan pinangan menggunakan bahasa adat yang disebut teda (bahasa adat).

Pihak keluarga wanita akan memberikan siri pinang sebagai suguhan dan menanyakan maksud kedatangan doma (keluarga mempelai laki-laki) atau klan penerima wanita pada saat itu doma (keluarga mempelai laki-laki) menyerahkan barang bawaan sambil meminta bibit padi (wini pare) dan bibit jagung (wini watara) sebagai tanda diterimanya pinangan.

c. Tahap ikat adat (kette katonga weri kawedo)

Setelah pinangan diterima tahap selanjutnya adalah ikat adat, sebagai lambang atau simbol kedua belah pihak keluarga untuk bersatu. Oleh karena itu yang harus dipersiapkan adalah (1) keluarga wanita, menyiapkan kain serta babi. (2) Keluarga pria menyiapkan hewan taguloka dan mamoli sebagai pengganti air susu ibu serta satu batang tombak dan rantai emas (lolo oma) sebagai bentuk kesatuan keluarga. Saat tiba di rumah orang tua wanita, pria akan membawa tombak dan lolo oma (rantai emas) yang akan diikat jadi satu, sebagai simbol kedua keluarga telah bersatu. Lalu rombongan pria menyerahkan hewan tagu loka (tanggungan om/paman) dan mamoli (rantai emas) Sebagai balasannya keluarga wanita akan memberikan kain (motif Sumba) serta satu babi yang sudah dibunuh dan satu lagi babi yang masih hidup, sebagai tanda kesepakatan jumlah belis (welli).

d. Tahap pindah dinding Turun Tangga/ikat Pindah (pala koro burru nauta/ ikat pindah)

Jika tahap ikat adat telah selesai, maka tahap selanjutnya adalah Tahap pindah dinding Turun Tangga/ikat pindah sehingga dapat dinyatakakan sah atau resmi secara adat wanita pindah ke suku pria.

\section{Prosesi pelaksanaan tradisi pemindahan perempuan atau pindah dinding Turun Tangga/ikat Pindah (pala koro burru nauta/ ikat pindah) \\ Adapun prosesi pelaksanaannya sebagai berikut.}

a. Membuka/Memulai Pembicaraan

Sapaan awal dimaksudkan untuk membuka pembicaraan dan mengajak semua keluarga serta undangan yang hadir untuk mengambil bagian dalam pembicaraan acara pindah adat perkawinan "Padikkina Minne pala koro burru nauta" pada masyarakat Desa Nyura Lele Kecamatan wewewa Timur Kabupaten Sumba Barat Daya Nusa Tenggara Timur". Di samping itu sapaan awal juga dapat dibuka dengan Doa sesuai keyakinan dan atau permintaan keluarga.

Pembicara/moderator/perwakilan keluarga diawali dengan ramah tamah dan pemberian sirih pinang serta kopi sebagai sambutan awal kekeluargaan untuk membina hubungan keakraban sekaligus meminta para jubir dan atau perwakilan kedua keluarga untuk mengambil tempat yang telah di siapkan oleh keluarga wanita. Untuk memulai pembicaraan orang tua laki-laki menyerahkan sebatang parang sebagai tanda menepati janji yang telah disepakati bersama pada saat kette katonga weri kawedo (ikat adat) dengan penuturan:

"Ne loddo tomana kira dukkina ndadi hiddage Umbamu, neti kabatana lendakana kira bokkarana Ndadi"

Terjemahan:

Hari ini tibalah waktu yang telah di sepakati oleh besanmu dan lni sebatang parang sebagai tanda penepatan janji

Pembicaraan tersebut dimaksudkan untuk membuka pembicaraan awal serta menginformasikan kepada semua yang hadir yang turut serta dalam kegiatan adat tersebut. Selanjutnya akan ditimpali kain dan sarung oleh orang tua (pihak perempuan) sebagai 
tanda persetujuan atau membenarkan yang disampaikan oleh pihak orang tua laki-laki dengan memberikan selembar kain dan sarung. Adapun tuturannya sebagai berikut:

"Neti ingngi, hinna takkadu paworo paduadama ba kira ba dadiwe ne loddo"

Terjemahan ;

Ini kain, benar sekali kesepakatan kita bersama bahwa hari ini adalah waktu yang kita janjikan

Setelah orang tua perempuan menerima kehadiran dan penyampaian orang tua atau jubir dari pihak lakilaki serta penerimaan pemberian berupa parang, pembicaraan akan dilanjutkan oleh orang tua atau jubir dari keluarga laki-laki sebagai berikut;

"Neti kabatana, ba waiga ne loddo netti paworo paduadada panga'a nga'a paenu Wee ne loddo banna manowaradoga umbagu, kaku pala koro burru nauta hidda ranga a kabullu (paworo ba) monno na"i 'manu".

Terjemahan:

Ini sebatang parang, kehadiran kami saat ini sesuai kesepakatan kita, kalau besan berkenan mengasihani kami, supaya hari ini juga kami mau membawa anak mantu kami dan hewan yang telah disepakti sejumlah 10 ekor hari ini juga sudah ada dan siap kami berikan serta ada babi 1 ekor

Adapun maksud tuturan tersebut untuk menjelaskan maksud dan kedatangan secara resmi dalam tikar adat pihak laki-laki ingin menjemput anak mantu sesuai dengan kesepakatan atau perjanjian pada saat Kette Katonga Weri Kawedo (Tahap Ikat adat). Selanjutnya, untuk menerima maksud dan tujuan kehadiran pihak keluarga laki-laki, maka orang tua perempuan atau orang yang diberi kuasa mensilahkan anak perempuannya untuk masuk ke tempat yang telah disiapkan (Balitonga) dan si perempuan langsung memberi salam berupa berjabatan tangan dan berciuman kepada sang calon suami dan memberi kaleku (tempat sirih pinang) kepada Bapak dan Mama mantu serta semua keluarga yang hadir.

Kedua orang tua perempuan menghampiri orang tua laki-laki untuk memberi salam berupa pemberian kain dan sarung kepada Umba (orang tua laki-laki) (inggi umba wee umba) selembar kain kepada Umba laki-laki dan selembar sarung kepada Umba (orang laki-laki) dari perempuan sambil berjabatan tangan dan berciuman. Kedua orangtua laki-laki akan membalas memberi sebatang parang dan seeokor hewan sebagai wujud rasa tanggung jawab dan penerimaan secara tulus kepada anak mantu/si perempuan (pawase). Adapun tuturannya;

"Nyado baba hinna takkadu omu (papalawi

lakawa minne monno wee Balena monno ngawu a li tilluna)".

Terjemahan ;

Benar yang disampaikan oleh besan, saya minta anak perempuan saya untuk mengambil tempat yang telah disiapkan dengan selempang kain dan salah satu dari keluarga perempuan membawa sejumlah kain yang disiapkan dan sudah diikat serta diletakkan di tengah-tengah ruang pertemuan.

b. Pemberian Tagu Loka (bagian Om/paman)

Setelah Pawasse (mempelai Perempuan) berada di Balitonga ((bale-bale yang telah disiapkan), Loka (Om/paman) dari perempuan memberikan selembar kain dan selembar sarung dan mengajukan permintaan berupa seekor kerbau atau kuda. Permintaan Om/paman (Loka) akan ditanggapi oleh orang tua lakilaki. Apabila permintaan dari paman tidak dipenuhi maka urusan pala koro burru nauta (pindah dinding turun tangga) akan tertunda dan atau tidak dapat dilanjutkan. Adapun tuturannya;

"Nennati lokana (wolla wee wolla ingngi) iya

Ndara padengina Lokana"

Terjemahan ;

Ini dari Omnya (satu Sarung dan satu kain) dan satu ekor Kuda permintaan Om.

Selanjutnya orang tua laki-laki melalui Juru bicara memberikan sebatang parang dan satu ekor kuda untuk Omnya. Dalam tradisi adat perkawinan masyarakat desa Nyura Lele Kecamatan Wewewa Timur Om di pandang sebagai Pintu berkat dalam kelangsungan hidup bahtera rumah tangga. Karena itu permintaan dari omnya wajib diberikan pada saat acara pinda adat. Permintaan omnya akan dilangsungkan sebagai berikut;

"(na yawe gasu keto) iya ndara ba hinna ge lokana na tenawe Omu ka yani Iya Ndara".

Terjemahan:

Ini sebatang parang dan satu ekor kuda untuk omnya.

Om/paman (Loka) dalam budaya masyarakat desa Nyura lele dipandang sebagai pintu berkat bagi kelangsungan hidup bahtera rumah tangga. Dalam Prosesi ini keluarga perempuan menanyakan dan menerima pemberian dari keluarga laki-laki sesuai permintaan berupa sebatang parang dan satu ekor kuda.

"Gei Ndara (kako etawa Ndara)"

Terjemahan :

Dimana itu kuda saya mau lihat

Tuturan tersebut sebagai bentuk permintaan Om yang harus dipenuhi dan apabila tidak dipenuhi, maka urusan pala koro burru nauta (pindah dinding turun tangga) akan ditunda dan atau tidak dapat dilanjutkan.

\section{c. Pemberian Tagu Umma kalada (Belis Untuk Rumah Besar)}

Orang yang tinggal dirumah besar akan memberikan selembar kain dan selembar sarung dan mengajukan permintaan seekor kerbau atau seekor kuda. Permintaan rumah besar (umma kalada) akan ditanggapi oleh orangtua laki-laki tentunya akan diwarnai dengan tawar 
nemawar sesuai kondisi ekonomi orang tua laki-laki. Adapun tuturannya:

"Kanyado na mababana lokana, neti tubana umma kalada padou kalaki lede wullu katowwa wolla wee wolla ingngi iya Ndara hinnage Umma Kalada".

Terjemahan :

Baik kalau omnya sudah selesai, bagian rumah besar sebagai tempat tali pusat dipotong dan rambut lahir dicukur ada satu kain dan satu sarung sebagai permintaan satu ekor kuda untuk rumah besar.

Apabila permintaan dari umma kalada (Rumah Besar) tidak dipenuhi maka urusan pala koro burru nauta akan tertunda dan atau tidak dapat dilaksanakan.

Istilah belis ini adalah tawar menawar rumah yang akan diberikan laki-laki kepada pihak perempuan, apabila harga cocok aka beli diterima dan apabila harga tidak cocok amaka belis di tolak, apabila ditolak maka proses pernikahan akan dihentikan sementara dulu baru setelah permintaan perempuan terpenuhi maka pernikahan dapat dilakukan sampai akhir [7].

d. Pemberian Imbalan Air Susu Ibu (Itta Kere Puaro

\section{Mata)}

Pengorbanan ibu merupakan hal yang tak bisa dilupakan dalam kehidupan setiap orang. Dalam budaya adat perkawinan masyarakat Desa Nyura Lele penghargaan terhadap seorang ibu merupakan salah satu hal terpenting sebagai bentuk balas budi. Adapun wujud dari Itta Kere Puaro Mata (pemberian imbalan air susu ibu) berupa satu buah mamoli emas atau dalam wujud Hewan Adapun tuturannya;

"Nenti dommo wolla wee wolla ingngi tubana innana a poddana pindala da durage durana. Tuba itta kere puoro mata iya Karambo Mane".

Terjemhan :

Ini lagi satu Sarung dan satu Kain bagian ibunya. Permintaan ibunya Satu Mamuli Emas dan atau satu ekor Kerbau Jantan.

Apabila permintaan dari ibu tersebut tidak dipenuhi maka urusan pala koro burru nauta (pindah dinding turun tangga) akan tertunda dan atau tidak dapat dilaksanakan.

\section{e. Urusan Belis}

Setelah semua urusan Tagu Loka (tanggungan om/paman), Tagu Umma Kalada (tanggungan rumah besar), dan Itta Kere Puaro Mata (pemberian imbalan air susu ibu) selesai, maka akan dilanjutkan dengan urusan belis (Wellina) dari orang tua perempuan. Dalam tahap ini proses tawar menawar belis berlangsung antara pihak perempuan dan pihak laki-laki tentunya melalui jubir masing-masing. Adapun tahapannya pada proses ini, sebagai berikut:

1) Pihak perempuan

Pada tahap ini perempuan memberikan sejumlah kain dan sarung sambil meminta sejumlah hewan atau belis (kerbau dan kuda) kepada orang tua laki- laki. Adapun tuturannya sebagai berikut: "nennati karatuka takka monno na’i wawi mate monno wawi moripa ka nyado neti panga"a da nga'a paenu nda wee paworo puuna pakaddo lawena neti ranga oro teki a kabullu (paworo bada) peina ole waidi?"

Terjemahan :

Ini kain dan sarung serta seekor babi (mati) dan Babi (hidup) sebagai barang bawaan. Berkaitan dengan hewan kesepakatan dan atau perjanjian kita yang sepuluh ekor, apakah hari ini dibawa

Tuturan tersebut merupakan pernyataan yang mengingatkan kembali tentang kesepakatan sebelumnya pada saat Kettena Katonga Weri Kawedo (ikat adat) serta pertanyaan langsung untuk memastikan keberadaan hewan yang telah disepakati dan dibawa pada hari ini.

Dalam tahap ini pula, akan dibicarakan tentang hewan yang sisa Leduna Umma Katonga (penempatan rumah besan) yakni pihak orang tua perempuan mengunjungi rumah baru (laki-laki) sebagai tempat hunian prempuan (suami istri). Menurut kebiasaan masyarakat desa Nyura Lele, pada saat orang tua perempuan mengunjungi rumah laki-laki tempat anak perempuannya akan disiapkan lagi hewan yang sebelumnya telah disepakati pada saat pala koro burru nauta (pindah dinding turun tangga). Adapun Tuturanya;

"Hiddi ranga akabullu tubana Lilli Kaleku Bengge Kadanu. Ka tubana ranga a engapona a Kabullu pirra baku dekewi?”

Terjemahan :

Itu hewan yang sepuluh untuk pindah rumah. Dan hewan yang sisa Sepuluh ekor kapan saya ambil (untuk kunjung anak perempuan)?

2) Pihak laki-laki

Orang tua laki-laki memberikan sebatang parang melalui juru bicara (ata panewe) sambil mengucapkan kata- kata berikut:

"Ne loddo bawaingga nda orokina bana tutuwe monno bana gennawe neti kupawee toddu kundo kupainggi paddo lako ndana toma toddu ndana dukkiwe tenda. Ku bole tuogu ku paluwe wekkigu, kukako kawodo katabaga netti barrami. Hinna wali kaiwe neti bawaingga ne loddo gaiwa ranga patalugu awaina pangindi monno nai manu patookowa manowara doga".

Terjemahan:

Kehadiran kami bukan karena cukup dan lengkapnya tapi kehadiran kami serba kekuranngan, dan dengan rendah hati kami mohon untuk dapat diterima apa adanya. Begitu pula kehadiran kami hannya membawa sekian hewan yang kami sanggup, semoga ayam itu dapat memberikan yang terbaik untuk kita semua.

Selanjutnya, dalam keadaan keterbatasan pihak keluarga laki-laki akan menyepakati dan memberikan kepastian memberikan hewan yang masih tersisah yang belum dilunasi pada saat Pala Koro Burru Nauta (pindah dinding turun tangga). Adapun tuturannya: 
"Peiko Ge neti baku millandengo baku paingngi paddo lako baku pawee toddu kundo nemme ndou ka amidi umba gu wulla 6 poddu pakuada ka leduna umma katonga kadekewi hiddi ranga a limma takka hiddi a limma neti ku manairodi bana dadi ndou ka deke wi".

Terjemahan:

Keadaan kami serba kekurangan. Namun, kami telah berusaha dengan semaksimal mungkin. Sepulang sebentar dari tempat ini, ada lima ekor yang siap diambil. Namun yang lima ekor, mohon sekiranya Besan (orang tua perempuan) untuk memberi waktu sambil kami berkebun dan bertani agar hasilnya dapat kami gunakan untuk melunasi hutang adat kami.

Selanjutnya jika pihak dari perempuan menyetujui apa yang disampaikan oleh pihak laki-laki, maka pembicaraan akan diakhiri dengan tuturan sebagai berikut;

"Kanyadoba Hinnako ge umbagu na tama ti'a na loga bukku neti a wolla ingngi tada na baku ndeibawe ne patekkina Umbagu."

Terjemahan;

Apa yang disampaikan oleh Besan kami terima. Oleh karena itu, ini satu kain dan satu sarung tanda pembicaraan serta janji yang kita utarakan bersama diikat secara adat.

Dengan disetujuinya pembicaraan tersebut, maka dengan sendirinya pembicaraan resmi antara Besan kedua belah pihak berakhir. Namun, pihak jubir yang diangkat pada pembicaraan tahap sebelumnya (Kette Katonga Weri Kawedo). Akan mempertanyakan keberadaan mereka, karena pembicaraan resmi sudah selesai. Adapun tuturannya, sebagai berikut;

3) Pihak Jubir

"Kanyado kanna ba babadowe torami yemmi a paumbana, kapeiwa ma yamme a nenna katukku tana rara kangali togo duawana, kada boka wiwi rato kowama- boka wiwi rato wa ma, kada mami wiwikoda kowama -mami wiwi kodawama. (ya badi pamama ata panewe kadapa dippa kadi bara kada dappa dakura ole kadi wawi) Kabata dakura wawi monno kaba 3 doppa"

Terjemahan ;

Ya, pembicaraan antara kedua belah pihak sudah selesai. Bagaimana dengan kami (jubir) sehingga kami jangan ditikam bersamaan dengan babi dan tidak diiris bersamaan dengan babi.

Selanjutnya, kedua belah pihak akan orang tua perempuan dan orang tua laki-laki akan memberikan sebatang parang sebagai tanda terlepas dari ikatan hewan bawaan yang akan ditikam dan diiris. Dengan berakhirnya seluruh pembicaraan, maka akan ditandai dengan acara penikaman hewan (babi) serta jamuan bersama. Selanjutnya akan diwarnai dengan pukul gong dan Pakallaka payawawu (senandung adat).

\section{TEMUAN ATAU DISKUSI}

Indonesia sebagai Negara kepulauan yang terbentang dari Sabang sampai Merauke memiliki kemajemukan suku, budaya dan tradisi sebagai ciri khas daerah masing-masing. Keanekaragaman budaya dan tradisi tersebut menjadi kebanggaan masyarakat dan diwariskan dari satu generasi kegenerasi selanjutnya. Sehingga keberagaman tersebut menjadi jati diri dan identitas bagi bangsa Indonesia yang membedakannya dengan bangsa-bangsa lain. Sebagai hasil karya manusia, tradisi melangsungkan hidup manusia dan penduduknya, masyarakat Indonesia sebagian besar hidup dalam tradisi merekat sejak berabad-abad, sehingga tradisi itu tumbuh dan berkembang berabad-abad.

Tradisi (bahasa latin: Traditio) atau kebiasaan dalam pengertian yang paling sederhana adalah, sesuatu yang telah dilakukan untuk sejak lama dan menjadi bagian dari kelompok masyarakat, biasanya dari suatu negara, kebudayaan, ras, suku, dan agama yang sama. Hal yang paling mendasar dari tradisi adalah, adanya informasi yang diteruskan dari generasi ke generasi baik tertulis maupun, tidak tertulis (seringkali) lisan"[8] [9].

Upaya manusia dalam rangka memenuhi kebutuhan hidupnya tertentu dengan mengandalkan kemampuan manusia sendiri untuk menjadikan alam sebagai objek yang dapat dikelola untuk memenuhi kebutuhan hidupnya" [10][11]. Jadi dapat dikatakan bahwa kebudayaan tersebut lahir sesungguhnya diakibatkan oleh keinginan manusia untuk memenuhi kebutuhan hidupnya, dalam bentuk tingkah laku, pola hidup, perekonomian, pertanian dan sebagainya kesesamaan aspek tersebut yang kemudian harus dipenuhi oleh manusia dalam kehidupan yang sekaligus secara spontanitas akan melahirkan kebudayaan atau tradisi.

Jadi tradisi budaya masyarakat Desa Nyura Lele, Kecamatan Wewewa Timur Kabupaten Sumba Barat Daya, merupakan sebuah tradisi budaya sejak lama lahir kemudian dilestarikan oleh masyarakat hingga sekarang ini. Adapun tata cara pelaksanaan upacara perkawinan adat padikkina mine pala koro burru nauta (pemindahan perempuan/ mempelai wanita pindah dinding turun tangga) melalui tahap perkenalan, tahap perkenalan adat, tahap ikat adat, dan tahap pindah dinding Turun Tangga/ikat Pindah. Kesadaran masyarakat tersbeut sangat tinggi sehingga budaya tradisi masih aktif dan sangat kultural dalam pelaksanaannya. Hal tersebut sependapat dengan penjelasan bahwa dalam pernikahan adat memiliki ciri khas yang dapat membedakan dengan daerah lain, perbedaan itu merupakan budaya Indonesia. Munculnya pernikahan adat dapat dilihat dalam proses sebelum dan setelah pernikahan [12]. Demikian juga, bahwa perkawinan adat dapat memberikan pesan simbolik dari alat-alat, benda-benda, perhiasan yang gunakan dalam tradisi perkawinan adat istiadat setiap daerah. Misalnya bentuk benda-benda adat tradisional adat Gayo yaitu 
Alang-alang, Batil Tembege, Dalung dan Ampang [13]. Sementara dalam tradisi perkawinan adat masyarakat Nyura Lele Suku Wee Leo Kabupaten Sumba Barat Daya adalah kain dan sarung, selembar kain, selembar sarung parang dan seeokor hewan.

Dalam proses pelaksanan tradisi pemindahan perempuan dalam istilah masyarakat Sumba disebut padikkina mine pala koro burru nauta (pemindahan perempuan/ mempelai wanita pindah dinding turun tangga) meliputi tahapan yaitu membuka/memulai pembicaraan, pemberian Tagu Loka (bagian om/paman), pemberian Tagu Umma Kalada (Belis untuk rumah besar), pemberian Imbalan Air Susu Ibu (Itta Kere Puaro Mata), dan urusan Belis. Setelah tahapan-tahapan dilaksanakan maka ditahap akhir atau kedua keluarga bermusyawarah kedua belah pihak akan orang tua perempuan dan orang tua laki-laki akan memberikan sebatang parang sebagai tanda terlepas dari ikatan hewan bawaan yang akan ditikam dan diiris. Dengan berakhirnya seluruh pembicaraan, maka akan ditandai dengan acara penikaman hewan (babi) serta jamuan bersama. Selanjutnya akan diwarnai dengan pukul gong dan Pakallaka Payawawu (senandung adat).

Proses tahapan yang dilakukan dalam perkawinan adat pemindahan perempuan suku Wee Leo kabupaten Sumba Barat melalui 5 tahapan, mulai perkenalan kedua mempelai, negosiasi mahar, pengantaran mahar dan resepsi pernikahan. Hal tersebut berbeda dengan pendapat bahwa dalam perkwinan adat, mahar sebagai simbol untuk mendapat seorang gadis, namun dalam hukum Islam tidak ada aturan yang mengatur tingginya mahar, akan tetapi kewajiban seorang laki-laki membawa mahar seberpa besarpun bisa diterima dan dilaksanakan sebagai pengganti air susu ibu [14]. Dengan hal yersbeut perkawinan adat dengan ketentuan dalam hukum Islam berbeda.

Sementara tradisi perkwinan adat memiliki nilai yaitu 1) Untuk menjaga kehormatan seorang laki-laki yang mau menikahi di hadapan seorang perempuan, supaya tidak disebut sebut sebagai laki-laki yang tidak mempunyai rasa cinta dan tanggung jawab pada istrinya. 2) Untuk menjaga nama baik keluarga, karena di dalam masyarakat adat perkawinan bukan hanya urusan suami istri, tetapi melibatkan kedua belah pihak atau keluarga kedua belah sehingga perilaku adat merupakan kebangga bagi suatu daerah [15].

Tradisi ini hingga sekarang masih ada dan dipertahankan oleh masyarakat Desa Nyurulele Suku Wee Leo sebagai sebagai salah satu rangkaian proses yang harus dilewati untuk melangsungkan suatu perkawinan adat, selain itu pula melalui Tradisi upacara perkawinan adat Padikina Minne Pala Koro Burru Nauta (pemindahan perempuan/mempelai wanita pindah dinding turun tangga) maka suatu perkawinan adat dapat dianggap syah atau memenuhi kriteria oleh masyarakat adat Desa Nyurulele Suku Wee Leo khususnya untuk keluarga mempelai laki-laki dan keluarga mempelai wanita. Senada dengan penjelasan dilakukan upacara adat sebagai simbol melestarikan budaya seperti tahapan praperkawinan, tahapana perkawinan dan tahapan pascaperkawinan. Ketiga tahapan perkawinan adat wajib dilakukan agar mendapatkan keselamatan kehidupan berumah tangga [16].

Sebagai Tradisi yang merupakan wariasan para leluhur, masyarakat Desa Nyurulele Suku Wee Leo percaya bahwa di setiap rangkaian proses yang dilakukan oleh mempelai laki-laki maupun perempuan dalam upacara perkawinan adat Padikina Minne Pala Koro Burru Nauta (pemindahan perempuan/mempelai wanita pindah dinding turun tangga) terdapat nilai-nilai budaya, adat-istiadat dan nilai sosial yang harus dijaga, dilestarikan dan dipertahankan kearifan serta keluhurannya. Hal inilah yang membuat masyarakat Sumba khususnya di Desa Nyurulele Suku Wee Leo menghargai aturan, hukum, dan nilai-nilai serta adatistiadat yang berlaku pada masyarakat, dan tidak berubah walau jaman sudah berubah karena budaya merupakan warisan leluhur yang harus dilestarikan oleh generasi muda.

Tradisi tersebut sejalan dengan penjelasan bahwa bagi penganut mistikus, keabsahan perkawinan tidak cukup dilakukan dihadapan pejabat formal seperti KUA dan Catatan Sipil. Keabsahan perkawinan bagi masyarakat adat harus dilakukan dihadapan alam, Tuhan, dan sesama disaksikan oleh seluruh anggota kerabat, tetangga, handai taulan, dan anggota masyarakat. Perkawinan yang demikian ditandai dengan upacara yaitu prosesi dari rumah penganten laki-laki ke rumah penganten perempuan atau sebaliknya sebagai bentuk pengumuman bahwa telah terjadi sebuah peristiwa sosial sekaligus peristiwa hukum yaitu kawin mawin [17] [18].

Jadi proses pelaksanaan tradisi tersebut merupakan aktivitas yang selalu dilakukan oleh kedua mempelai dalam perkawinan adat masyarakat sumba pada umumnya. Dengan demikian, aktivitas ataupun tradisi perkawinan adat merupakan simbol kebudayaan yang hidup dimasyarakat untuk dilestarikan untuk mendapatkan kehidupan yang berkah bagi pasangan suami istri suku Wee Leo Kabupaten Sumba Barat Daya.

\section{E. SIMPULAN DAN SARAN}

Proses Tradisi pemindahan perempuan (Padikina Minne Pala Koro Burru Nauta) pada perkawinan adat masyarakat desa Nyura Lele suku Wee Leo kabupaten Sumba Barat Daya meliputi tahapan perkenalan, tahapan perkenalan adat, tahapan ikat adat dan tahapan pindah dinding turun tangga/ikat pindah. Dalam proses pelaksanan tradisi pemindahan perempuan dalam istilah masyarakat Sumba disebut padikkina mine pala koro burru nauta (pemindahan perempuan/ mempelai wanita pindah dinding turun tangga) meliputi yaitu membuka/memulai pembicaraan, pemberian Tagu Loka 
(bagian om/paman), pemberian Tagu Umma Kalada (Belis untuk rumah besar), pemberian Imbalan Air Susu Ibu (Itta Kere Puaro Mata), dan urusan Belis.

Tradisi perkawinan masyarakat sumba ini harus tetap dijaga dan dilestarikan agar menghasilkan nilainilai kebudayaan. Dengan demikian menyarankan kepada pemerintah daerah setempat agar tetap melestarikan tradisi tersbeut melalui kebijakan yang melestarikan kebudayaan daerah. Penelitian berikutnya dapat mengkaji tentang regulasi peraturan adat, nilainilai yang terkandung dalam tradisi.

\section{UCAPAN TERIMA KASIH}

Penulis mengucapkan terima kasih kepada semua pihak yang telah membantu menyelesaiakan penelitian ini yang senantiasa memberikan data dan informasi kepada penulis sehingga penelitian ini selesai dengan baik.

\section{DAFTAR RUJUKAN}

[1] R. M. Koentjaraningrat, Introduction to the Peoples and Cultures of Indonesia and Malaysia. Menlo Park, Calif.: Cummings Publishing Company, 1975.

[2] F. Kamal, "Perkawinan adat jawa dalam kebudayaan indonesia," Khasanah Ilmu-Jurnal Pariwisata Dan Budaya, vol. 5, no. 2, 2014.

[3] M. Lede, Z. Bidaya, and Z. Anshori, "Tradisi Belis dalam Perkawinan Adat Suku Weelewo," Civ. Pendidikan-Penelitian-Pengabdian Pendidik. Pancasila dan Kewarganegaraan, vol. 5, no. 2, pp. 14-21, 2017.

[4] C. D. Steven and T. A. R. Yunanto, "Pengaruh Belis Dalam Masyarakat Sumba," Insight J. Pemikir. dan Penelit. Psikol., vol. 15, no. 2, pp. 204-212, 2019.

[5] T. Subekti, "Sahnya Perkawinan Menurut UndangUndang Nomor 1 Tahun 1974 Tentang Perkawinan Ditinjau Dari Hukum Perjanjian,” J. Din. Huk., vol. 10, no. 3, pp. 329-338, 2010.

[6] D. Kleden, "Belis dan Harga Seorang Perempuan Sumba (Perkawinan Adat Suku Wewewa, Sumba Barat Daya, NTT)," Stud. Budaya Nusant., vol. 1, no. 1, pp. 18-27, 2017.

[7] H. A. Sosroatmodjo and A. W. Aulawi, Hukum Perkawinan di Indonesia. Bulan Bintang, 1981.

[8] M. M. Syakhlani, "Dilema Perkawinan Usia Dini: Antara Tradisi dan Regulasi," MUHARRIK J. Dakwah dan Sos., vol. 2, no. 2, pp. 137-149, 2019.

[9] P. Sztompka, The sociology of social change. Blackwell Oxford, 1994.

[10] P. Sztompka, "Sosiologi perubahan sosial $=$ the sociology of social change," 2014.

[11] A. P. A. Ambarwati and I. L. Mustika, "Pernikahan Adat Jawa Sebagai Salah Satu Kekuatan Budaya Indonesia," in Prosiding Seminar Nasional Bahasa dan Sastra Indonesia (SENASBASA), 2018, vol. 2, no. 2.

[12] A. Mustafa and A. Amri, "Pesan Simbolik Dalam Prosesi Pernikahan Adat Gayo Di Kecamatan Blangkejeren, Gayo Lues," J. Ilm. Mhs. Fak. Ilmu Sos. Ilmu Polit., vol. 2, no. 3, 2017.

[13] M. Ikbal and P. Enrekang, "Uang panaik" dalam perkawinan adat suku Bugis Makassar," Indones. $J$. Islam. Fam. Law, vol. 6, pp. 1-25, 2016.

[14] A. Pattiroy and I. Salam, "Tradisi doi'menre'dalam pernikahan adat bugis di jambi," Al-Ahwal J. Huk. Kel. Islam, vol. 1, no. 1, pp. 89-116, 2016.
[15] E. Satriana, "Makna Ungkapan Pada Upacara Perkawinan Adat Bulukumba di Desa Buhung Bundang Kec. Bontotiro Kab. Bulukumba," $J$. Humanika, vol. 3, no. 15, 2017.

[16] D. Rato and H. Alting, Hukum adat:(suatu pengantar singkat memahami hukum adat di Indonesia). LakBang Pressindo, 2011.

[17] D. Rato, Hukum perkawinan dan waris adat di Indonesia: sistem kekerabatan, perkawinan dan pewarisan menurut hukum adat. LB (LaksBang), 2015

[18] N. Abubakar, "Tradisi latama kareyoo dalam pernikahan adat masyarakat muslim suku Sumba perspektif hukum keluarga (studi di desa Pero Konda Kecamatan Kodi Kabupaten Sumba Barat Daya)." Universitas Islam Negeri Mataram, 2019. 
